\title{
Osgood-Schlatter disease
}

\author{
Patrick Joseph Maher, Jonathan S Ilgen
}

Division of Emergency Medicine, University of Washington, Seattle, Washington, USA

\section{Correspondence to} Dr Patrick Joseph Maher, maherp@uw.edu
To cite: Maher PJ, Ilgen JS. BMJ Case Rep Published

online: [please include Day

Month Year] doi:10.1136/

bcr-2012-007614

\section{DESCRIPTION}

A 14-year-old man presented to our emergency department with 3 days of progressively worsening right knee pain that was exacerbated by movement. The patient played basketball and had a history of asthma, but he denied any recent trauma or prior knee pain. Systemic symptoms, including fever, weight changes and fatigue, were absent. On examination, he had tenderness at the tibial tuberosity and a small effusion, but no overlying erythema or limited range of motion. Knee films demonstrated patellar tendon oedema (figures 1 and 2, small arrow) and a sliver-like osseous density anterior to apophysis of the tibial tuberosity (figure 1, large arrow), confirming the diagnosis of OsgoodSchlatter disease.

Robert Osgood and Carl Schlatter independently described this painful overuse condition of the tibial tuberosity in $1903 .{ }^{1}$ Osgood-Schlatter disease is common in active adolescents, possibly caused by multiple small avulsion fractures from contractions of the quadriceps muscles at their insertion into the proximal tibial apophysis. ${ }^{2}$ The disease is associated with growth spurts, and may be bilateral in up to $30 \%$ of cases. ${ }^{3}$

Patients typically present with the gradual onset of pain, swelling and tenderness of the tibial tuberosity, exacerbated by activities that extend the knee against resistance. ${ }^{1}$ Treatment for Osgood-Schlatter disease consists of reduced physical activity, analgesia and physical therapy. ${ }^{13}$ Symptoms are typically self-limited, and patients can be instructed to

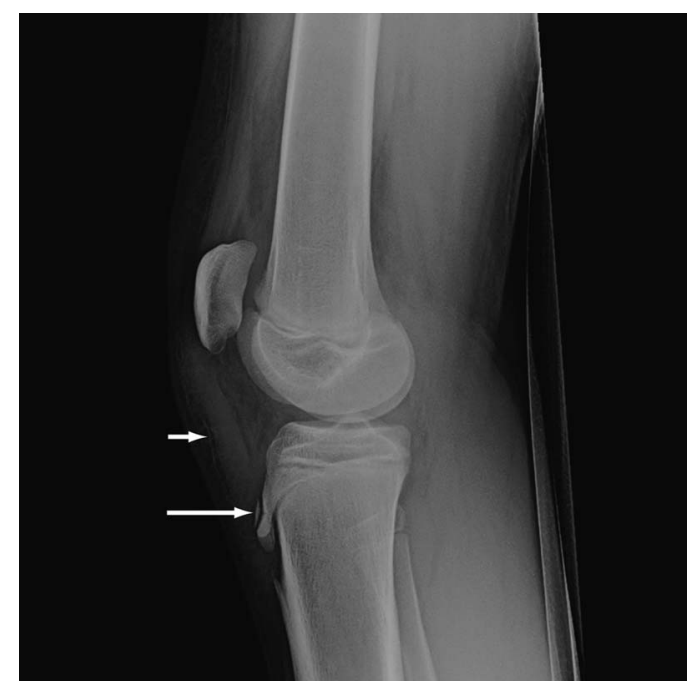

Figure 1 Lateral view of knee demonstrating patellar tendon oedema (small arrow) and a sliver-like osseous density anterior to apophysis of the tibial tuberosity (large arrow).

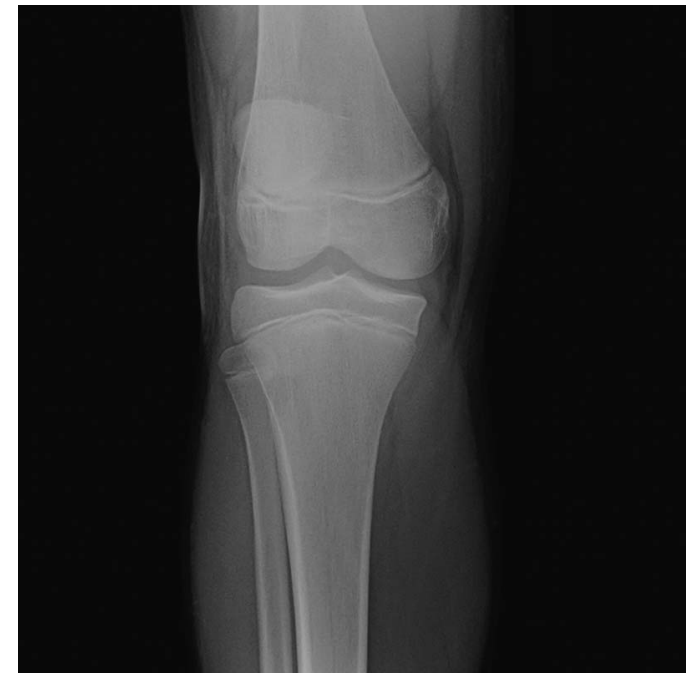

Figure 2 Anterioposterior view of knee.

gradually return to activity once the pain improves. Complete recovery is expected when the tibial growth plate closes, although some patients who have recurrent symptoms into adulthood may require surgical treatment. ${ }^{1}$

\section{Learning points}

- Osgood-Schlatter disease is common in active adolescents, who commonly present with knee pain localised to the tibial tubercle that worsens with knee extension.

- Treatment consists of reduced physical activity, analgesia and physical therapy.

- Symptoms are typically self-limited, but some patients with recurrent symptoms into adulthood may require orthopaedic referral for surgical treatment.

Competing interests None.

Patient consent Obtained.

\section{REFERENCES}

1 Weiler R, Ingram M, Wolman R. 10-Minute consultation. Osgood-Schlatter disease. BMJ 2011;343:d4534.

2 de Lucena GL, dos Santos Gomes C, Guerra RO. Prevalence and associated factors of Osgood-Schlatter syndrome in a population-based sample of Brazilian adolescents. Am J Sports Med 2011;39:415-20.

3 Gholve PA, Scher DM, Khakharia S, et al. Osgood Schlatter syndrome. Curr Opin Pediatr 2007;19:44-50. 
Copyright 2013 BMJ Publishing Group. All rights reserved. For permission to reuse any of this content visit http://group.bmj.com/group/rights-licensing/permissions.

BMJ Case Report Fellows may re-use this article for personal use and teaching without any further permission.

Become a Fellow of BMJ Case Reports today and you can:

- Submit as many cases as you like

- Enjoy fast sympathetic peer review and rapid publication of accepted articles

- Access all the published articles

- Re-use any of the published material for personal use and teaching without further permission

For information on Institutional Fellowships contact consortiasales@bmjgroup.com

Visit casereports.bmj.com for more articles like this and to become a Fellow 